\title{
Growth, yield and grain nutrients response of wheat (Triticum aestivum $L$.) to biochar, lime and farmyard manure amendment of the croplands in southern Ethiopia.
}

mekdes lulu ( $\nabla$ mekdes@springernature.com )

Madda Walabu University

Bekele Lemma

Hawassa University

Legesse Hidoto

Southern Agricultural research Institute

\section{Research}

Keywords: Biochar, Cropland, Grain nutrient concentration, Growth parameters, Yield component

Posted Date: May 8th, 2020

DOI: https://doi.org/10.21203/rs.3.rs-26449/v1

License: (9) (1) This work is licensed under a Creative Commons Attribution 4.0 International License. Read Full License 


\section{Abstract}

Background: Soil fertility decline in agricultural land is due to intensive cropping system, shortening of the fallow period, reduced manure application, extensive use of crop residues as fuelor fodder and removal of ground cover. This study investigated the effect of biochar (BC), lime and farmyard manure (FYM) on growth, yield and grain nutrient of wheat on two cropland sites in southern Ethiopia.

Result: The effect of site was significant $(P<0.05)$ for most parameters investigated, indicating the influence of soil type. The effects of BC, lime, and FYM were significant $(p \leq 0.001)$ on straw yield, grain yield, and total biomass. However, BC (5 tha -1$)$ produced the highest straw yield, grain yield, and total biomass. Similarly, BC and lime significantly $(P<0.001)$ affected plant height, and tiller numbers and productivity. BC $(5$ tha -1$)$ gave the highest plant height, total tillers, and productive tillers, maximum number of seeds per spike, while FYM (10 tha - 1$)$ produced the highest spike length. Biochar significantly $(P<0.05)$ increased the concentrations of $\mathrm{P}$ and $\mathrm{K}$ in wheat grain. The highest effect on grain $\mathrm{Ca}$ concentration was from the application of lime while the highest on grain $\mathrm{N}$ concentration was from FYM (10 tha -1 ).

Conclusion: The effect from BC was attributed to improvements in soil pH, CEC, nutrient availability and water retention. Thus $\mathrm{BC}$ has a good potential as a soil amendment for smallholder farm crop production.

\section{Background}

Wheat (Triticum aestivum, L.) is globally one of the most important cereal crops in terms of area and production. Ethiopia is the largest wheat producer in sub-Saharan Africa (Minot et al. 2015) covering an estimated area of 1.7 million ha and with an annual production of 4.6 million tons (CSA 2018). Ethiopia's wheat productivity has increased from 1.3 tha $^{-1}$ in 1994 (CSA 1995) to 2.7 tha $^{-1}$ in 2018 (CSA 2018). This productivity has grown significantly over the past decades due to government programs and initiatives encouraging agricultural growth and food security. However, the current wheat production is inadequate to fill Ethiopia's needs (Minot et al. 2015) due to low soil fertility and soil management practices (Gebresselassie 2002). In 2013/14 the country imported 1.39 million metric tons, which equals 34 percent of the domestic production and more than 160 percent of the marketed wheat in the country (Minot et al. 2015).

Soil fertility decline constrains crop production in Sub Saharan Africa (SSA). The nutrient balance for SSA appears to be negative because nutrient loses are greater than nutrient inputs (Agegnehu et al. 2014). Intensive cropping systems, shortened fallow periods, reduced manure applications, extensive use of crop residues for fuel or fodder, and removal of ground cover, all lead to soil fertility decline. In addition soils have low fertility due to a low rate of fertilizer use and insufficient organic matter application in a form biochar or compost (Gebrekidan 2003). The major constraints to agricultural production in Ethiopian highlands could be the decline in soil organic matter, nutrient imbalance, as well as soil acidity problems (Agegnehu et al. 2014). The combined application of organic and inorganic fertilizer is a productive approach to improve soil fertility (Efthimiadou et al. 2010).

Studies in SSA, including Ethiopia, have reported the effect of inorganic and organic fertilizers on crop yield (Efthimiadou et al. 2010; Waseem et al. 2013). The benefits of inorganic fertilizer have been widely demonstrated since the green revolution (Vanlauwe et al. 2010); however, most smallholder farmers in SSA 
cannot afford the recommended fertilizer. Moreover, the application of inorganic fertilizer alone is not a sustainable solution for improving soil fertility (Agegnehu et al. 2014). Other studies have reported the effect of liming materials on crop yield (Negash and Rezene 2015). Few studies reported the use of farmyard manure (FYM) on grain yield of wheat products (Efthimiadou et al. 2010). Ranva and Singh (2006) investigated the effect of Vermicompost on wheat growth parameters and yield attributes. Enujeke (2013) have investigated the effect of poultry manure on maize productivity in the Asaba area of Delta State.

Biochar (BC) is a C-rich, stable, product obtained by thermal decomposition of plant biomass at a temperature between 400 and $700^{\circ} \mathrm{C}$ in oxygen-limited combustion (Lehmann and Joseph 2009). Studies have reported the effect of the $\mathrm{BC}$ amendment on yield components for a variety of crops in different parts of the world (Agboola and Moses 2015; Haileselassie et al. 2015; Faruqueet al. 2017). For instance, a study by Faruque et al. (2017) investigated the utilization of BC in mulberry plant productivity. The effect of BC was studied on growth and yield attributes in the Mediterranean climate conditions (Manue/ et al. 2014). A review of biochar studies indicated that most studies have been carried out in developed countries rather than developing countries (Agegnehu et al. 2016). Few published reports are available on the investigation of the influence of BC on crop yield in SSA (Abewa et al. 2013; Hailesilasie et al. 2015). Therefore, this study's objective was to investigate the effect of $\mathrm{BC}$, lime, and FYM on growth, yield and nutrient concentrations in the grain and straw of wheat (Triticum aestivum, L.) at two cropland sites in Wolaita Zone, Southern Ethiopia.

\section{Materials And Methods}

\subsection{Experimental site}

A field experiment was conducted on agricultural fields at the Gununo Hamus and Waja Kero kebeles of Damot Sore and Sodo Zuria districts of the Wolaita Zone in southern Ethiopia, respectively (Fig. 1). Soddo, the capital of Wolaita zone, is located $329 \mathrm{~km}$ south of Addis Ababa. The geographical coordinates of Gununo Hamusis $37^{\circ} 39^{\prime} 0^{\prime \prime}-37^{\circ} 43^{\prime} 0^{\prime \prime} \mathrm{E}, 6^{\circ} 55^{\prime} 0^{\prime \prime}-7^{\circ} 5^{\prime} \mathrm{O}^{\prime} \mathrm{N}$ and Waja Kero at $37^{\circ} 40^{\prime} 0^{\prime \prime}-37^{\circ} 45^{\prime} 0^{\prime \prime} \mathrm{E}, 6^{\circ} 50^{\prime} 0^{\prime \prime}-6^{\circ} 55^{\prime} \mathrm{O}^{\prime \prime} \mathrm{N}$. Gununo Hamus is located $44 \mathrm{~km}$ southwest of Soddo town, while the Waja Kero is $5 \mathrm{~km}$ west of Soddo. The elevation at Gununo Hamus and Waja Kero ranges from 1900 to $2100 \mathrm{~m}$ above sea level (asl). The study areas' topography is level to sloping land with slopes less than $16 \%$. The rainfall in the area is characterized by a bimodal distribution pattern with the main rainy season (Meher) occurring between June and the end of September and Belg, the shorter season, from late February to late March or early April. The mean monthly average temperatures $\left({ }^{\circ} \mathrm{C}\right)$ and mean monthly total rainfall $(\mathrm{mm})$ of one year within the two sites are shown in Fig. 2. According to the FAO/UNESCO soil map of the world, the dominant soil at Gununo Hamus is Ochric Andosol and that of Waja Kero is Eutric Nitisols (http://www.fao.org/geonetwork/srv/en/metadata.show\%3 Fid $=14116$ ).

\subsection{Experimental materials, treatments and Design}

The wheat variety 'Kakaba' was used as a test crop which was obtained from the Wolaita zone agricultural office. Lime, BC, and FYM were used as soil amendments. The experimental design was a randomized complete block in a factorial arrangement with three replications. The 27 treatments applied included BC, FYM, and lime, with each treatment applied at three rates. Farmyard manure (cow dung decomposed for two 
months before application) was collected from farms in the study areas. It was manually applied at rates 0,5 , and 10 tha $^{-1}$ two weeks before sowing and incorporated into the soil using a spade within 24 hours. Biochar, was finely crushed charcoal, collected from commercial charcoal sellers in Wolaita Soddo town. The charcoal producers use the acacia tree species Acacia penninrvisis (locally called "Odorua"). The biochar was ground and sieved $\left(0.25 \mathrm{~mm}\right.$ mesh size) before application. It was manually applied at rates 0,2 , and 5 tha $^{-1}$ two weeks before sowing and incorporated within 24 hours using a spade. The limestone $\mathrm{CaCO}_{3}$ with a purity of $98 \%$ was used as the source of lime. The $\left(\mathrm{CaCO}_{3}\right)$ was obtained from the Wolaita Zone Office of Agriculture. Lime was applied at three rates based on the lime requirement determination (LR). It was manually applied to the soil surface $(0-15 \mathrm{~cm})$ a month before sowing. The lime requirement was determined by the Shoemaker, Mclean, and Pratt (SMP) buffer method to raise the pH to a target value of 6.5 (Shoemaker et al. 1961). Accordingly, pH 5.6 and 5.4 were taken for determining the lime rate used at Gununo Hamus and Waja Kero sites, respectively. After determining the lime requirement, lime was applied at the rates of $0,2.9,5.7$ tha $^{-1}$ at Gununo Hamus and $0,3.75,7.5$ tha $^{-1}$ at Waja Kero.

The inorganic fertilizers were obtained from Southern Nations Nationalities and Peoples Regional Bureau of Agriculture and Natural Resources, soil testing laboratory. The mineral fertilizer plots received $120 \mathrm{~kg} \mathrm{~N} \mathrm{ha}^{-1}$ as urea (46-0-0, N-P-K), $30 \mathrm{~kg} \mathrm{P} \mathrm{ha}^{-1}$ as triple superphosphate (0-21-0, N-P-K) and $52 \mathrm{~kg} \mathrm{~K} \mathrm{ha}^{-1}$ as muriate of potash (0-0-60, N-P-K). Half the $\mathrm{N}$ and full $\mathrm{P}$ and $\mathrm{K}$ were applied just before sowing. The remaining $\mathrm{N}$ was applied as a top dressing at the tillering stage (35 days after sowing). All the treatments were assigned randomly to the plots within a block. The spacing between plots and blocks was $0.5 \mathrm{~m}$ and $1.5 \mathrm{~m}$, respectively. Wheat was sown at the rate of $100 \mathrm{~kg} \mathrm{ha}^{-1}$ in a plot size of $3 \mathrm{~m}$ by $2 \mathrm{~m}$ with a row spacing of $20 \mathrm{~cm}$.

\subsubsection{Agronomic data collection and measurement}

Ten plants were randomly selected from each plot and plant height was measured from the base to the spike tip, excluding awns, and averaged for each plot (Bhatta et al. 2012). From this data, the numbers of total and productive tillers per plant were selected. The effective and non-effective tiller plants were counted from each plot randomly and averaged for each plot. Spike length, excluding the awns, was measured and averaged for each plot. The number of grains per spike was determined, and filled and unfilled grains spike ${ }^{-1}$ were counted and averaged for each plot. Total biomass was calculated after sun drying from the total weight of harvest at each plot. Grain yield was measured for each plot after air drying and then weighed and the straw yield obtained by the difference between total biomass and grain yield. Like grain yield, straw yield and total biomass were expressed as $\mathrm{kg} \mathrm{ha}^{-1}$. Yield components were calculated using standard protocols (Pask et al. 2012). From these data, the number of hundred seeds weights were counted from a sample of each plot, after sun drying, and measured by an electrical balance and converted into thousand-grain weights in $\mathrm{kg}$. Harvest index (\%) was calculated as the fraction of grain yield to the total biomass times 100 , as described by Huhm (1990). Weeds were managed first by hand-weeding followed by two hoeings using a manually operated wheel-hoe. The crop was harvested by hand and separated into grains (yield) and biomass.

\subsubsection{Plant tissue analysis}


Grain samples were collected from each plot after harvest. The samples were air dried then ground in a stainless steel Wiley mill and sieved $(0.5 \mathrm{~mm}$ mesh size). Calcium and $\mathrm{K}$ were determined following the acid digestion method with $\mathrm{H}_{2} \mathrm{O}_{2} / \mathrm{H}_{2} \mathrm{SO}_{4}$ (Okalebo et al. 2002). Calcium was analyzed by the atomic absorption spectrophotometer, while $\mathrm{K}$ was analyzed by flame photometer. Phosphorous was measured following the method in Murphy and Riley (1962). The percent nitrogen content was determined by the Kjeldahl method as described by Jackson (1958).

\subsection{Statistical analysis}

All of the data were analyzed using analysis of variance (ANOVA) with a statistical analysis system (SAS) program (SAS, 2017). The least significant difference (LSD) test was used to separate significantly different treatment mean at $\mathrm{P} \leq 0.05$ level.

\section{Result}

\subsection{Effect of biochar, lime and farmyard manure on growth parameters}

The effect of site was significant $(P<0.05)$ for all growth parameters, and the effect of amendments was greater for Gununo Hamus than Waja Kero. The effects of $B C$, lime as well as interaction effects of site $x B C$, site $\times$ FYM, site $\times B C \times F Y M$ and site $\times B C \times$ lime were highly significant $(P<0.001)$ on plant height $($ Table 1$)$. As presented in Table 2, plant height was higher at 5 tha $^{-1}$ of $B C$ for both sites. The effects of $B C$, lime as well as interaction effects of site $\times B C$, site $\times B C \times$ lime were highly significant $(p \leq 0.001)$ on the number of total and productive tillers (Table 1). The total tillers and productive tillers were higher at 5 tha $^{-1}$ of $B C$ for both sites (Table 2). Moreover, the effects of BC, FYM, lime and the interaction effects of site $x$ BC, site $x$ FYM and site $x$ lime were significant on spike length and seed per spike (Table 1). The longest spike length was at 10 tha ${ }^{-1}$ FYM in both sites (Table 2). Likewise, the maximum number of seeds per spike was at 5 tha $^{-1} \mathrm{BC}$ in both sites (Table 2).

\subsection{Effect of biochar, lime and farmyard manure on yield and yield components}

The effect of site was significant $(P<0.001)$ for most yield and yield components and the effect of amendments was greater for Gununo Hamus than Waja Kero. The effects of BC, FYM, lime as well as interaction effects of site $x B C$, site $x$ lime and site $x B C \times$ lime were highly significant $(p \leq 0.001)$ on grain yield, straw yield and total biomass (Table 3 ). The highest grain yield, straw yield, and total biomass were found for BC amendment ( 5 tha $\left.^{-1}\right)$ in both sites (Table 4). The effects of BC, FYM, lime and interaction effect of site $\times B C$ and $B C \times F Y M$ were highly significant $(p \leq 0.001)$ on thousand seed weight (Table 3$)$. The heaver thousand seed weight was at 10 tha $^{-1}$ of FYM and 5 tha $^{-1}$ of BC in Gununo Hamus and Waja Kero, respectively (Table 4). The effects of $B C, F Y M$ and interaction effects of site $\times B C$ and $B C \times F Y M$ were highly significant ( $p \leq 0.001$ ) on harvest index (Table 3). The highest harvest index was found at 10 tha $^{-1}$ of FYM and 5 tha $^{-1}$ of $\mathrm{BC}$ in Gununo Hamus and Waja Kero, respectively (Table 4).

\subsection{Effects of biochar, lime and farmyard manure on grain nutrient content of bread wheat}


The site has a significant effect $(P<0.001)$ on grain nutrient content of wheat (Table 5$)$. The effects of $B C$, $F Y M$, lime were highly significant ( $p \leq 0.001$ ) on the concentration of $N, P, K$ and $C a$ in grain of wheat (Table 3). The highest grain $\mathrm{N}$ content was found at 10 tha $^{-1}$ of FYM and 5 tha $^{-1} \mathrm{BC}$ for both sites (Table 6 ). The highest grain $\mathrm{P}$ was found at 5 tha $^{-1} \mathrm{BC}$ for both sites (Table 6). The highest grain $\mathrm{K}$ was found at 5 tha $^{-}$

1 of $\mathrm{BC}$ in Gununo Hamus and at 5 tha $^{-1}$ of $\mathrm{BC}$ for both sites (Table 6). The highest grain Ca was found with lime of 5.7 and 7.5 tha $^{-1}$ in Gununo Hamus and Waja Kero sites, respectively (Table 6). The interaction effects of $B C$ and lime on wheat grain $N, P$ and $K$ were highly significant $(p \leq 0.001)$ (Table 5). The highest grain $N$ content $\left(4.66 \%\right.$ ) was found at 5 tha $^{-1}$ of BC with 2 tha $^{-1}$ lime (Fig. 3). Similarly, the highest grain $P(3.56 \%)$ was found from the application of 5 tha $^{-1} \mathrm{BC}$ with 2 tha $^{-1} \mathrm{Lime}$ (Fig. 4). Moreover, the highest grain $\mathrm{K}$ content (2.84) was from the highest-rated of BC and lime interaction (Fig. 5).

\section{Discussion}

The study showed that acacia biochar (BC) amendment could have a greater effect on wheat growth, yield and grain nutrient concentration than farmyard manure and lime on cropland in southern Ethiopia. Consistent with the present study, BC showed a positive impact on plant growth parameters for annual crops such as maize, wheat, tomato and rice (Dunlop et al. 2015; Haileselassie et al. 2015; Agegnehu et al. 2016). Biochar from Canadian agricultural biomass improved the growth of rice and sorghum (Asai et al. 2009). Agboola and Moses (2015) showed that the application of rice husk BC to soil improved soybean yield. Wheat grain yield increased from application of oil mallee waste BC (Solaiman et al. 2010). Similarly, mesquite BC increased grain and straw yields of wheat (Haileselassie et al. 2015). Maize BC amendment significantly increased the yield of maize and cassava (Abiven et al. 2015). Hossain et al. (2010) observed that sludge BC amendment increased the yield of cherries and tomatoes. Similarly, Dunlop et al. (2015) found that soil amended with BC from green tomato residue improved the growth of tomatoes. In contrast, other studies demonstrated that BC from woodchips did not affect the growth and yield of rice and leaf beet (Lai et al. 2013). The finding of Borsari (2011) showed that maple BC did not affect the growth parameters of peas and wheat. The significant variation of $B C$ on plant growth and yield parameters among different studies in different sites could be ascribed to the effect of environmental factors (Shahzad et al. 2007).In a review of BC, Lehmann et al. (2006) indicated $B C$ in general improved plant growth parameters and yield in the tropical environment. The effect of the $\mathrm{BC}$ amendment on plant growth and yield parameters could be associated with improvements in soil pH, CEC, nutrient availability and water retention (Liang et al. 2014). The increase in plant growth and yield parameters was attributed to the improved soil nutrient supply and increased uptake of plant nutrients (Lehmann et al. 2006). Thus BC addition to croplands enhance water retention, sorption capacity, nutrient availability, and soil organic $\mathrm{C}$. Moreover, $\mathrm{BC}$ characteristics also vary between experiments depending on feedstock, pyrolysis temperature, and rate of application (Streubel et al. 2011, Bird 2015). Biochar amendment had positive influence on most wheat growth, yield and grain nutrient parameters in both soil types (sites), but in a different manner. The influence of $\mathrm{BC}$ on different wheat parameters was in general greater for Ochric Andosol than for Eutric Nitisols. Consistently, BC improved peanut biomass and pod yield in a different way in two soil types (Xu et al. 2015). Amendment of agricultural soils with BC had a variable effect on soil properties depending on soil types (Streubel et al. 2011), which could be attributed to the BC influence on crop parameters. 
In the present study, the grain N content was highest for FYM; grain P and $\mathrm{K}$ content was highest for $\mathrm{BC}$; and Ca content was highest for lime. Grain N, P, K and Ca concentrations were in the reported sufficiency range for all treatments, with $4-5 \%, 0.24-0.36 \%, 2-3 \%$ and $0.28-0.42 \%$,respectively (Barrett et al.,2017). The highest application of FYM $\left(10\right.$ tha $\left.^{-1}\right)$ rate significantly increased the $\mathrm{N}$ concentration in wheat grain. Likewise, Zahir and Ishaq (2006) reported that the maximum $\mathrm{N}$ concentration in grain wheat was found from higher FYM. The next highest $\mathrm{N}$ concentration was from BC. The finding of Major et al. (2010) reported that $\mathrm{N}$ concentration in maize grains increased with the application of ponderosa pine wood $\mathrm{BC}$. BC increased $\mathrm{P}$ concentration in grain. Likewise, Gonzaga et al. (2017) found that biosolids (sludge) BC addition increased P concentration in grain of maize providing improved seed formation and maturation thereby improving the above ground structure of maize. However, cassava stem BC had no significant effect on $\mathrm{P}$ content in green beans (Prapagdee and Tawinteung, 2017). The highest BC application (5 tha ${ }^{-1}$ ) contributes to high $\mathrm{K}$ concentration in wheat grain due to improved exchangeable K in the soil. The finding by Prapagdee and Tawinteung (2017) showed increased K content in the grain bean by BC addition. Similarly, Jeffrey et al. (2019) found that Lodgepole pine chip BC addition significantly increased the concentration of $\mathrm{K}$ in grain corn. With liming, increased $\mathrm{Ca}$ concentration in grain may indicate the increase in crop growth and yield due to the amelioration of Al toxicity. This is in agreement with findings by Beukes et al. (2012) who reported that liming increased the Ca concentration in grain of maize crop. The high $\mathrm{Ca}$ in grain wheat concentration with a higher lime rate provides the soil have high soil exchangeable Ca attributed to improved Ca concentration in the soil (Bolanet al. 2003).

\section{Conclusion}

From this study's results, it may be concluded that wheat growth, yield, and yield components, as well as grain nutrients, were significantly influenced by different cropland levels of BC, lime and farmyard manure depending on soil type. This study demonstrated that the application of a higher $\mathrm{BC}$ rate was superior to the other soil amendments in its impact on growth parameters, yield, yield components, and grain nutrients. Biochar amendment had positive influence on most wheat growth, yield and grain nutrient parameters in both soil types (sites), but greater influence in the site with Ochric Andosol soil type than the site with Eutric Nitisols soil type. The impact of BC was greater on plant height, spike length, seed per spikelet, tillers, grain yield, straw yield and total biomass at 5 tha $^{-1}$. The highest harvest index and the heaver thousand seed weight were produced in the higher farmyard manure rate at 10 tha $^{-1}$. Likewise, the addition of a higher $\mathrm{BC}$ rate at 5 tha ${ }^{-1}$ produced the higher nutrients of $\mathrm{P}$ and $\mathrm{K}$ in grain wheat. However, the higher $\mathrm{Ca}$ in grain was obtained from the higher lime rate at 5.7 tha $^{-1}$ and 7.5 tha $^{-1}$ owing to high Ca content in lime. The higher $\mathrm{N}$ in grain was obtained at a higher FYM rate at 10 tha $^{-1}$. The results showed that $\mathrm{BC}$ has enormous potential for the improvement of wheat growth and yield parameters as well as grain nutrients. Thus, BC has great potential for use as a soil amendment on smallholder croplands in southern Ethiopia. We recommend further studies to be carried out to investigate the optimum amount of BC needed for wheat production at different levels of mineral fertilizer.

\section{List Of Abbreviations}


(BC) biochar, (FYM) farmyard manure, (GN) grain nitrogen, (GP) grain phosphorous, (GK) grain Potassium, (G

Ca) grain calcium.

\section{Declarations}

\section{Ethics approval and consent to participate}

Not applicable

\section{Consent for publication}

Not applicable.

\section{Availability of data and materials}

Not applicable.

\section{Competing interests}

The authors declare that they have no competing interests.

\section{Funding}

Ministry of Education provided fund only for sample collection and laboratory analysis.

\section{Authors' contributions}

ML: collected, analyzed, interpreted the data and made the final write up which was part of his Doctoral thesis in Soil Science at Hawassa University, Ethiopia. BL and LH, as co-authors edited the final manuscript. All authors read and approved the final manuscript.

\section{Acknowledgements}

This research was funded by the grant given to graduate students from the Ethiopian Ministry of Education. The authors are grateful to Robert Sturtevant for editing the English.

\section{References}

1. Abewa A, Yitaferu B, Selassie YG, Amare TT (2013) The role of biochar on acid soil reclamation and yield of teff (Eragrostistef [Zucc] Trotter) in northwestern Ethiopia. J Agric Sci 6: 1-12.

2. Abiven S, Hund A, Martinsen V, Cornelissen G(2015) Biochar amendment increases maize root surface areas and branching: a shovelomics study in Zambia. Plant Soil 395: 45-55.

3. Agboola K, Moses SA (2015) Effect of biochar and cowdung on nodulation, growth and yield of soybean (Glycine max I. Merrill) Int JAgric Biol 4(4):154-160.

4. Agegnehu G, Bass AM, Nelson PN, Bird MI (2016) Benefits of biochar, compost and biochar-compost for soil quality, maize yield and greenhouse gas emissions in a tropical agricultural soil. JSci totalEnviron 
543: 295-306.

5. Agegnehu G, Lakew B, Nelson P N (2014) Cropping sequence and nitrogen fertilizer effects on the productivity and quality of malting barley and soil fertility in the Ethiopian highlands. Arch Agron Soil Sci60: 1261-1275.

6. Asai H, Samson BK, Stephan HM, Songyikhangsuthor K, Homma K, Kiyono Y, Inoue Y, Shiraiwa T, Horie T (2009) Biochar amendment techniques for upland rice production in Northern Laos: 1. Soil physical properties, leaf SPAD and grain yield. Field Crops Res 111: 81-84.

7. Barrett W, Chu P, Coleman G, Goff D, Griffith L, Hohla J, Jones N, Pohlman K, Poole H, Spiva C, Zwiep J (2017) Agronomy hand book. Midwest laboratories, INC.1311, B. Street, Omaha, NE. 68144, 402, 334, 7770.

8. Beukes DJ, Mapumulo TC, Fyfield TP, Jezile GG (2012) Effects of liming and inorganic fertilizer application on soil properties and maize growth and yield in rural agriculture in the Mbizana area, Eastern Cape province, South Africa. South Afr J plant soil 29:3-4.

9. Bhatta M, Eskridge KM, Rose DJ, Santra DK, Baenziger PS, Regassa T (2017) Seeding rate, genotype, and top dressed nitrogen effects on yield and agronomic characteristics of winter wheat. Crop Sci57:951963.

10. Bird, MI (2015) Test procedures for biochar analysis in soils. In: Lehmann, J Joseph, S. (Eds.), Biochar for Environmental Management: Science Technology and Implementation, 2nd ed. Routledge, London, pp. 677-714.

11. Bolan N, Adriano DC, Curtin D (2003) Soil acidification and liming interactions with nutrient and heavy metal transformation and bioavailability. Advances in Agron. 78: 215-272.

12. Borsari B (2011) A Preliminary Study of the Effect of Biochar from Maple (Acer spp.) on Root Growth of Selected Agronomic Crops. International Symposium on Growing Media, Composting and Substrate Analysis. 1013:17-22.

13. CSA (Central Statistics Agency) (2018) Agricultural Sample Survey 2017/2018. Volume I. Report on Area and Production of Major Crops (Private Peasant Holdings, Meher Season). Statistical Bulletin 586. Addis Ababa.

14. CSA (Central Statistics Agency) (1995) Agricultural sample survey (1994/95) report: Private peasant holding (Statistical Bulletin) Vol. III Central Statistics Agency, Addis Ababa, Ethiopia.

15. Dunlop SJ, Arbestain MC, Bishop PA, Wargent JJ (2015) Closing the loop: use of biochar produced from tomato crop green waste as a substrate for soilless, hydroponic tomato production. Hort Sci 50: 15721581.

16. Efthimiadou A, Bilalis D, Karkanis, Froud B (2010) Combined organic and inorganic fertilization enhances soil quality and increased yield, photosynthesis and sustainability of sweet maize crop. Aust Crop Sci 4 (9): 722-729.

17. Enujeke EC (2013) Effects Of Poultry Manure On Growth And Yield Of Improved Maize In Asaba Area of Delta State, Nigeria. J Agric Vet Sci 4: 24-30.

18. Faruque A, Shorifull.Md, Toufiql.Md(2017) Biochar amendment improves soil fertility and productivity of mulberry plant. Eurasian J Soil Sci 6 (3): 226 - 237. 
19. Gebrekidan H (2003) Grain yield response of sorghum (Sorghum bicolor) to tied ridges and planting methods on Entisols and Vertisols of Alemaya area, Eastern Ethiopian highlands. J Agric Rural Dev 104(2):113-128.

20. Gebreselassie Y (2002) Selected chemical and physical characteristics of soils of the Adet research center and its testing sites in North-Western Ethiopia. Eth J Nat Resour 3:199-215.

21. Gonzaga MIS, Mackowiak CL, Comerford NB, da Veiga Moline EF, Shirley JP, Guimaraes DV (2017) Pyrolysis methods impact biosolids-derived biochar composition, maize growth and Soil Till. Res 165: 59-65.

22. Haileselassie G, Haileselassie B, Berhe D, Belay T (2015) Effect of Biochar on Yield and Yield Components of Wheat and Post-harvest Soil Properties in Tigray, Ethiopia. J Fertil Pestic 6(2):158.

23. Hossain MK, Strezov V, Yin Chan KY, Nelson P (2010) Agronomic properties of wastewater sludge biochar and bioavailability of metals in production of cherry tomato (Lycopersiconesculentum). Chemosphere 78(9):1167-1171.

24. Huhm M (1990) Components on the calculation of mean harvest indices. J Agon Crop Sci 165: 86-93.

25. Jackson ML (1958) Soil Chemical Analysis. Prentice Hall, Inc., Englewood Cliffs. New Jersey.

26. Jeffrey M, Gilbert C, Thomas F, Donald W, Kenneth C (2019) Stone Designer Biochars Impact on Corn Grain Yields, Biomass Production, and Fertility Properties of a Highly-Weathered Ultisol. Environ 6:64.

27. Lai WY, Lai CM, Ke GR, Chung RS, Chen CT, Cheng CH, Pai CW, Chen SY, Chen CC (2013) The effects of woodchip Biochar application on crop yield, carbon sequestration and greenhouse gas emissions from soils planted with rice or leaf beet. J Taiwan Inst Chem Eng 44 (6): 1039-44.

28. Lehmann J, Gaunt J, Rondon M (2006) Biochar sequestration in terrestrial ecosystems- a review. Mitigation Adapt Strateg Glob Chang 11(2): 403-

29. Lehmann J, Joseph S (2009) Biochar for Environmental Management: Science and Technology. Earthscan. London UK.

30. Liang F, Li G, Lin Q, Zhao X (2014) Crop yield and soil properties in the First 3 years after biochar application to a calcareous Soil $J$ Integr Agric13:525-532.

31. Major J, Rondon M, Molina D, Susan J.R, Lehmann J (2010) Maize Yield and Nutrition during 4 Years after Biochar Application to a Colombian Savanna Oxisol. Plant Soil 333: 117-128.

32. Manuel O, José Antonio A, Vidal B, María C, Del C, Antonio G, Mariano F, Rafael V(2014) Wheat growth and yield responses to biocharaddition under Mediterranean climate conditions. J Bio Fertil Soils 50(8) DOI 10.1007/s00374-014-0959-y.

33. Minot N, Warner J, Lemma S, Kassa L, Gashaw A, Rashid S (2015) The Wheat Supply Chain in Ethiopia: Patterns, Trends, and Policy Options. Int Food Policy Res Inst Washington, DC.

34. Murphy J, Riley JP (1962) A modified single solution method for the determination of phosphate in natural waters. Anal Chem Acta 27:31-36.

35. Negash F, RezeneY (2015) Nitrogen and Phosphorus Fertilizers Rate as Affecting Common Bean Production at Areka, Ethiopia. J Agric Crops 1(3):33-37.

36. Okalebo JR, Gathua KW, Womer PL (2002) Laboratory methods of soil and plant analyses: a working manual, 2nd Ed. TSBF - CIAT and SACRED Africa, Nairobi, Kenya.128p. 
37. Pask AJD, Pietragalla J, Mullan D, Reynolds MP (2012) Physiological breeding II: A field guide to wheat phenotyping. CIMMYT, D.F, Mexico. Producing bioenergy, permanently sequestering carbon, while improving soil and water quality. Agron J 100:178-181.

38. Prapagdee S, Tawinteung N (2017) Effects of biochar on enhanced nutrient use efficiency of green bean, Vigna radiata L. Environ Sci Pollu Res 24:9460-9467.

39. Ranva RS, Singh KP( 2006) Effect of integrated nutrient management with vermin compost on productivity of wheat (Triticumaestivum). Indian J Agron 26 (2):34-37.

40. SAS (Statistical Analysis System Institute) (2017) SAS/STAT user's guide. Proprietary software version 9.4. SAS Inst Inc Cary NC.

41. ShahzadMA, U, Sahi ST, Khan MM, Ehsanullah , Ahmad M(2007) Effect of sowing dates and seed treatment on grain yield and quality of wheat. Pakistan JAgric Sci44 (4):581-583.

42. Shoemaker HE, McLeanE.O, Pratt PF (1961) Buffer methods for determining the lime requirement of soils with appreciable amounts of extractable aluminum. Soil Sci Soc Am 25:274-277.

43. Solaiman ZM, Blackwell P, Abbott LK, Storer P (2010) Direct and residual effect of biochar application on mycorrhizal root colonisation, growth and nutrition of wheat. Soil Res 48: 546-554.

44. Streubel JD, Collins HP, Garcia-Perez M, Tarara J, Granatstein D, Kruger CE (2011) Influence of contrasting biochar types on five soils at increasing rates of application. Soil Sci Soc Am J 75: 1402-1413.

45. Vanlauwe B, Bationo A, Chianu J, Giller K.E, Merckx R, Mokwunye U, Ohiokpehai O, Pypers P, Tabo R, Shepherd, KD, Smaling EMA, Woomer PL, Sanginga N (2010) Integrated soil fertility management: operational definition andconsequences for implementation and dissemination. J Outlook Agric 39:1724.

46. Waseem M, Ali A, Tahir M, Mehmood K (2013) Mitigative effect of diverse use of nitrogen sources on bulk density, organic matter and grain yield of hybrid maize. Pakistan J Anim Plant Sci 23(3):900-905.

47. Xu CY, Bai SH, Hao Y, Rachaputi RCN, Wang H, Xu Z, Wallace H (2015) Effect of biochar amendment on yield and photosynthesis of peanut on two soil types. Eviron Sci Pollut Res 22:6112-6125.

48. Zahir S, Ishaq A(2006) Effect of integrated use of farm yard manure and urea on yield and nitrogen uptake of wheat. J Agric Biol Sci 1(1) pages.

\section{Tables}


Table 1

ANOVA for the Effect of BC, FYM and lime and their interaction effect on growth parameters of Bread wheat.

\begin{tabular}{|c|c|c|c|c|c|c|c|}
\hline Source of variation & DF & Plant & Spike & Seedsper spike & \multicolumn{2}{|c|}{ Total tillers } & Productive tillers \\
\hline Site & 1 & ** & ** & ** & ** & ** & \\
\hline$B C$ & 2 & ** & ** & ** & ** & ** & \\
\hline FYM & 2 & ns & * & * & ns & ns & \\
\hline Lime & 2 & ** & ** & ** & * & * & \\
\hline Site $\times$ BC & 2 & $\star \star$ & ** & ** & * & * & \\
\hline Site x FYM & 2 & * & * & * & ns & ns & \\
\hline Site $x$ Lime & 2 & ns & * & ** & ns & ns & \\
\hline$B C \times F Y M$ & 4 & ns & ns & ns & ns & ns & \\
\hline BC $x$ Lime & 4 & ns & ns & ns & ns & ns & \\
\hline FYM x Lime & 4 & ns & ns & ns & ns & ns & \\
\hline Site $\times B C \times F Y M$ & 4 & * & ns & ns & ns & ns & \\
\hline Site $x$ BC $x$ Lime & 4 & ** & ns & ns & ** & ** & \\
\hline Site $x$ FYM $x$ Lime & 4 & ns & ns & ns & ns & ns & \\
\hline BC $x$ FYM $x$ Lime & 4 & ns & ns & ns & ns & ns & \\
\hline Site $x$ BC $x$ FYM $x$ Lime & 8 & ns & ns & ns & ns & ns & \\
\hline
\end{tabular}


Table 3

ANOVA for the Effect of BC, FYM, lime and their interaction on total biomass, Grain yield, straw yield and thousand seed weight and harvest index of Bread wheat.

\begin{tabular}{|c|c|c|c|c|c|c|c|}
\hline Location & $\begin{array}{l}\text { Treatment } \\
\left(\text { tha }^{-1}\right)\end{array}$ & $\begin{array}{l}\text { Plant he } \\
\text { (cm) }\end{array}$ & & $\begin{array}{l}\text { Spike } \\
\text { length(cm) }\end{array}$ & $\begin{array}{l}\text { Seed per } \\
\text { spike/m² }\end{array}$ & $\begin{array}{l}\text { Total tillers/ } \\
\mathrm{m}^{2}\end{array}$ & $\begin{array}{l}\text { Productive } \\
\text { tillers } / \mathrm{m}^{2}\end{array}$ \\
\hline & & 0 & \multirow{5}{*}{$\begin{array}{l}82.94^{\mathrm{c}} \\
83.08^{\mathrm{b}} \\
83.60^{\mathrm{a}} \\
1.46\end{array}$} & \multirow{5}{*}{$\begin{array}{l}6.17^{b} \\
6.83^{b} \\
7.44^{a} \\
0.17\end{array}$} & \multirow{5}{*}{$\begin{array}{l}368^{\mathrm{b}} \\
392^{\mathrm{a}} \\
397^{\mathrm{a}} \\
1.42\end{array}$} & \multirow{5}{*}{$\begin{array}{l}549^{b} \\
558^{\text {ba }} \\
626^{a} \\
0.08\end{array}$} & $514^{\mathrm{b}}$ \\
\hline & $B C$ & 2 & & & & & $558^{\text {ba }}$ \\
\hline & & & & & & & \multirow{2}{*}{$\begin{array}{l}580^{\mathrm{a}} \\
0.24\end{array}$} \\
\hline & & 5 & & & & & \\
\hline & & \multicolumn{2}{|l|}{$\mathrm{LSD}_{5 \%}$} & & & & \\
\hline \multirow{11}{*}{$\begin{array}{l}\text { Gununo } \\
\text { Hamus }\end{array}$} & & 0 & \multirow{4}{*}{$\begin{array}{l}82.80 \\
84.14 \\
82.69 \\
\text { ns }\end{array}$} & \multirow{4}{*}{$\begin{array}{l}7.48^{\mathrm{c}} \\
7.49^{\mathrm{b}} \\
7.81^{\mathrm{a}} \\
0.20^{\mathrm{a}}\end{array}$} & \multirow{4}{*}{$\begin{array}{l}382 \\
382 \\
392 \\
\text { ns }\end{array}$} & \multirow{4}{*}{$\begin{array}{l}548 \\
585 \\
586 \\
\text { ns }\end{array}$} & \multirow{4}{*}{$\begin{array}{l}527 \\
563 \\
576 \\
\text { ns }\end{array}$} \\
\hline & FYM & 5 & & & & & \\
\hline & & 10 & & & & & \\
\hline & & $\mathrm{LSD}_{5 \%}$ & & & & & \\
\hline & & 0 & \multirow{3}{*}{$\begin{array}{l}82.11 \\
83.73 \\
83.79 \\
\text { ns }\end{array}$} & \multirow{3}{*}{$\begin{array}{l}7.47 \\
7.65 \\
7.66 \\
\text { ns }\end{array}$} & \multirow{3}{*}{$\begin{array}{l}380 \\
387 \\
381 \\
\text { ns }\end{array}$} & \multirow{3}{*}{$\begin{array}{l}536 \\
576 \\
588 \\
\text { ns }\end{array}$} & \multirow{3}{*}{$\begin{array}{l}535 \\
571 \\
581 \\
\text { ns }\end{array}$} \\
\hline & Lime & $\begin{array}{l}2.9 \\
5.7\end{array}$ & & & & & \\
\hline & & $\mathrm{LSD}_{5 \%}$ & & & & & \\
\hline & & 0 & \multirow{4}{*}{$\begin{array}{l}66.05^{\mathrm{c}} \\
70.06^{\mathrm{b}} \\
73.90^{\mathrm{a}} \\
1.46\end{array}$} & \multirow{4}{*}{$\begin{array}{l}6.17^{\mathrm{b}} \\
6.83^{\mathrm{b}} \\
7.44^{\mathrm{a}} \\
0.17\end{array}$} & \multirow{4}{*}{$\begin{array}{l}284^{\mathrm{c}} \\
316^{\mathrm{b}} \\
353^{\mathrm{a}} \\
0.71\end{array}$} & \multirow{4}{*}{$\begin{array}{l}254^{\mathrm{c}} \\
302^{\mathrm{b}} \\
377^{\mathrm{a}} \\
0.24\end{array}$} & $249^{b}$ \\
\hline & $B C$ & 2 & & & & & \multirow{3}{*}{$\begin{array}{l}298^{\mathrm{b}} \\
374^{\mathrm{a}} \\
0.24\end{array}$} \\
\hline & DU & 5 & & & & & \\
\hline & & $\mathrm{LSD}_{5 \%}$ & & & & & \\
\hline \multirow{4}{*}{$\begin{array}{l}\text { Waja } \\
\text { Kero }\end{array}$} & & 0 & \multirow{4}{*}{$\begin{array}{l}66.28^{b} \\
69.91^{b a} \\
70.81^{a} \\
1.46\end{array}$} & \multirow{4}{*}{$\begin{array}{l}6.73^{\mathrm{b}} \\
6.80^{\mathrm{ba}} \\
6.91^{\mathrm{a}} \\
0.20\end{array}$} & \multirow{4}{*}{$\begin{array}{l}317^{\mathrm{b}} \\
317^{\mathrm{b}} \\
326^{\mathrm{a}} \\
0.71\end{array}$} & \multirow{4}{*}{$\begin{array}{l}297^{c} \\
307^{b} \\
328^{a} \\
0.24\end{array}$} & \multirow{4}{*}{$\begin{array}{l}294^{b} \\
303^{\text {ba }} \\
324^{a} \\
0.24\end{array}$} \\
\hline & FYM & 5 & & & & & \\
\hline & & & & & & & \\
\hline & & $\mathrm{LSD}_{5 \%}$ & & & & & \\
\hline \multirow[t]{3}{*}{ Lime } & & $68.22^{c}$ & \multirow{3}{*}{$\begin{array}{l}6.56^{\mathrm{c}} \\
6.82^{\mathrm{b}} \\
7.06^{\mathrm{a}} \\
0.17\end{array}$} & & & $282^{b}$ & $248^{b}$ \\
\hline & $\begin{array}{l}3.75 \\
7.5\end{array}$ & $70.09^{b}$ & & & $317^{b}$ & $306^{\mathrm{b}}$ & $296^{\mathrm{b}}$ \\
\hline & $\mathrm{LSD}_{5 \%}$ & $\begin{array}{l}71.69^{a} \\
1.46\end{array}$ & & & $\begin{array}{l}332^{\mathrm{a}} \\
0.71\end{array}$ & $\begin{array}{l}374^{a} \\
0.24\end{array}$ & $\begin{array}{l}342^{\mathrm{a}} \\
0.24\end{array}$ \\
\hline
\end{tabular}


Table 4

Effects of BC, FYM and lime on total biomass, grain yield, straw yield, thousand seed weight and harvest index of Bread wheat.

\begin{tabular}{|c|c|c|c|c|c|c|c|}
\hline Source of variation & DF & $\begin{array}{l}\text { Total } \\
\text { biomass }\end{array}$ & \multicolumn{2}{|c|}{$\begin{array}{l}\text { Grain } \\
\text { yield }\end{array}$} & $\begin{array}{l}\text { Straw } \\
\text { yield }\end{array}$ & $\begin{array}{l}\text { Thousand seed } \\
\text { weight }\end{array}$ & $\begin{array}{l}\text { Harvest } \\
\text { index }\end{array}$ \\
\hline Site & 1 & ** & ** & $\star \star$ & $\star \star$ & ** & \\
\hline $\mathrm{BC}$ & 2 & $\star \star$ & ** & $\star \star$ & $\star \star$ & ** & \\
\hline FYM & 2 & ** & ** & $\star \star$ & * & * & \\
\hline Lime & 2 & $\star \star$ & ** & $\star \star$ & $\star \star$ & ns & \\
\hline Site $\times$ BC & 2 & $\star \star$ & ** & $\star \star$ & * & * & \\
\hline Site $x$ FYM & 2 & ns & ns & ns & ns & ns & \\
\hline Site $x$ Lime & 2 & ** & ** & $\star \star$ & ns & ns & \\
\hline$B C \times F Y M$ & 4 & ns & ns & * & $\star \star$ & * & \\
\hline BC $x$ Lime & 4 & ns & ns & ns & ns & ns & \\
\hline FYM x Lime & 4 & ns & ns & ns & ns & ns & \\
\hline Site $x$ BC $x$ FYM & 4 & ns & ns & ns & ns & ns & \\
\hline Site $x$ BC $x$ Lime & 4 & ** & ** & $\star \star$ & ns & ns & \\
\hline Site $x$ FYM x Lime & 4 & ns & ns & ns & ns & ns & \\
\hline BC $x$ FYM $x$ Lime & 4 & ns & ns & ns & ns & ns & \\
\hline $\begin{array}{l}\text { Site x BC x FYM x } \\
\text { Lime }\end{array}$ & 8 & ns & ns & ns & ns & ns & \\
\hline
\end{tabular}


Table 5

ANOVA for the Effect of BC, FYM and lime and their interaction effect on grain $N, P, K$ and Ca concentration of Bread wheat.

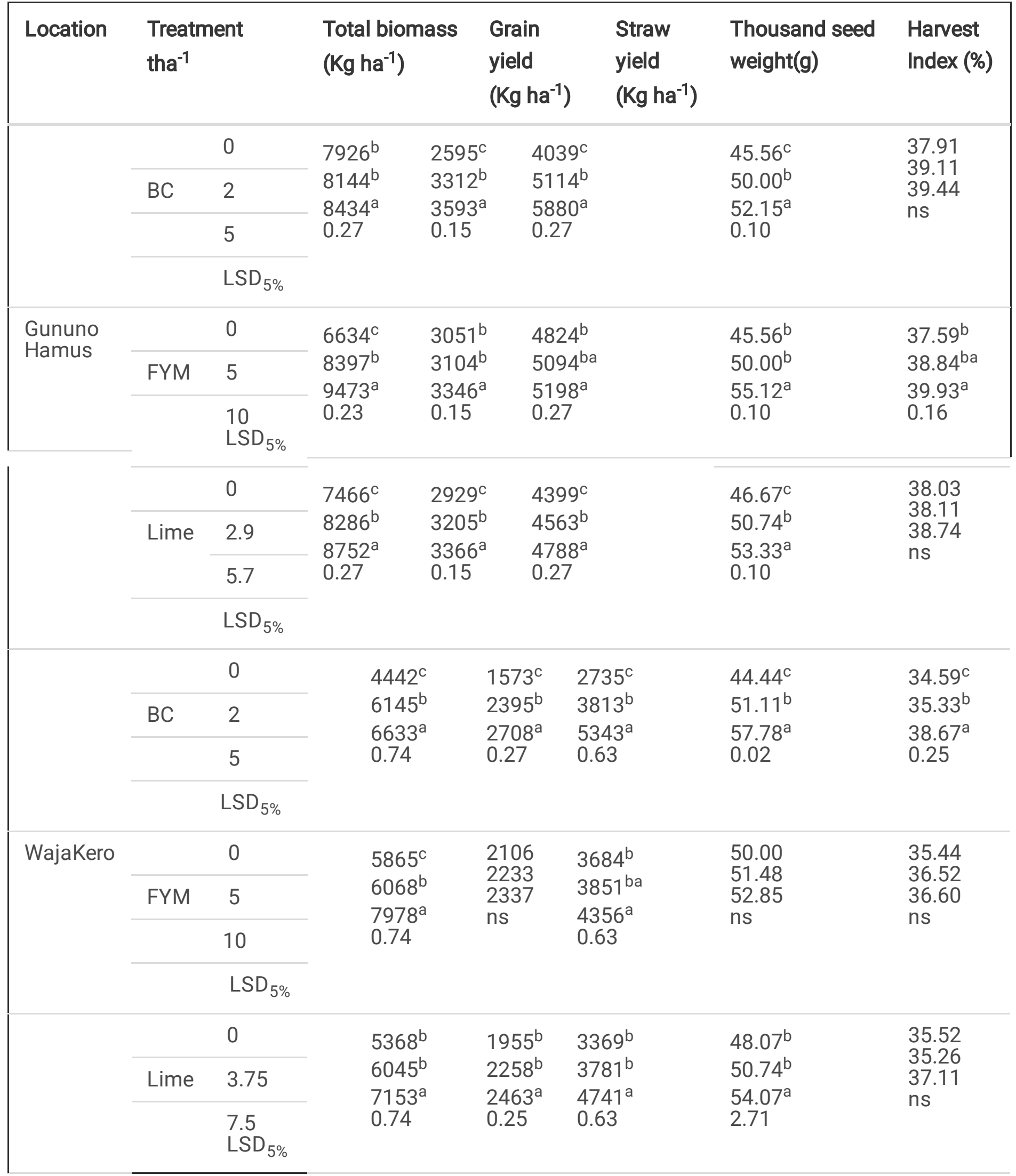


Table 6

Effect of BC, FYM and lime on grain N, P, K and Ca concentration of bread wheat.

\begin{tabular}{|c|c|c|c|c|c|}
\hline Source of variation & DF & GN & GP & GK & GCa \\
\hline Site & 1 & $\star * *$ & 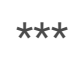 & 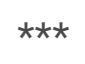 & $\star \star \star ~$ \\
\hline $\mathrm{BC}$ & 2 & $\star * *$ & $\star * *$ & $\star * *$ & * \\
\hline FYM & 2 & $\star * \star$ & * & $\star \star \star$ & $\star \star$ \\
\hline Lime & 2 & $\star * *$ & ** & ** & 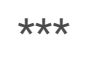 \\
\hline Site $\times B C$ & 2 & ns & $\star \star \star ~$ & ns & ns \\
\hline Site x FYM & 2 & ns & ns & ns & ns \\
\hline Site $\mathrm{x}$ Lime & 2 & ns & ns & ns & ns \\
\hline$B C \times F Y M$ & 4 & ns & ns & * & ns \\
\hline BC $x$ Lime & 4 & * & $\star \star$ & ** & ns \\
\hline FYM x Lime & 4 & ns & ns & ** & ns \\
\hline Site $x$ BC $x$ FYM & 4 & ns & ns & ns & ns \\
\hline Site $x$ BC $x$ Lime & 4 & ns & ns & ns & $\star \star$ \\
\hline Site $x$ FYM x Lime & 4 & ns & ns & ns & ns \\
\hline BC $x$ FYM x Lime & 4 & ns & ns & $\star \star$ & ns \\
\hline Site $\times$ BC $\times$ FYM $x$ Lime & 8 & ns & ns & ** & ns \\
\hline
\end{tabular}

Figures 


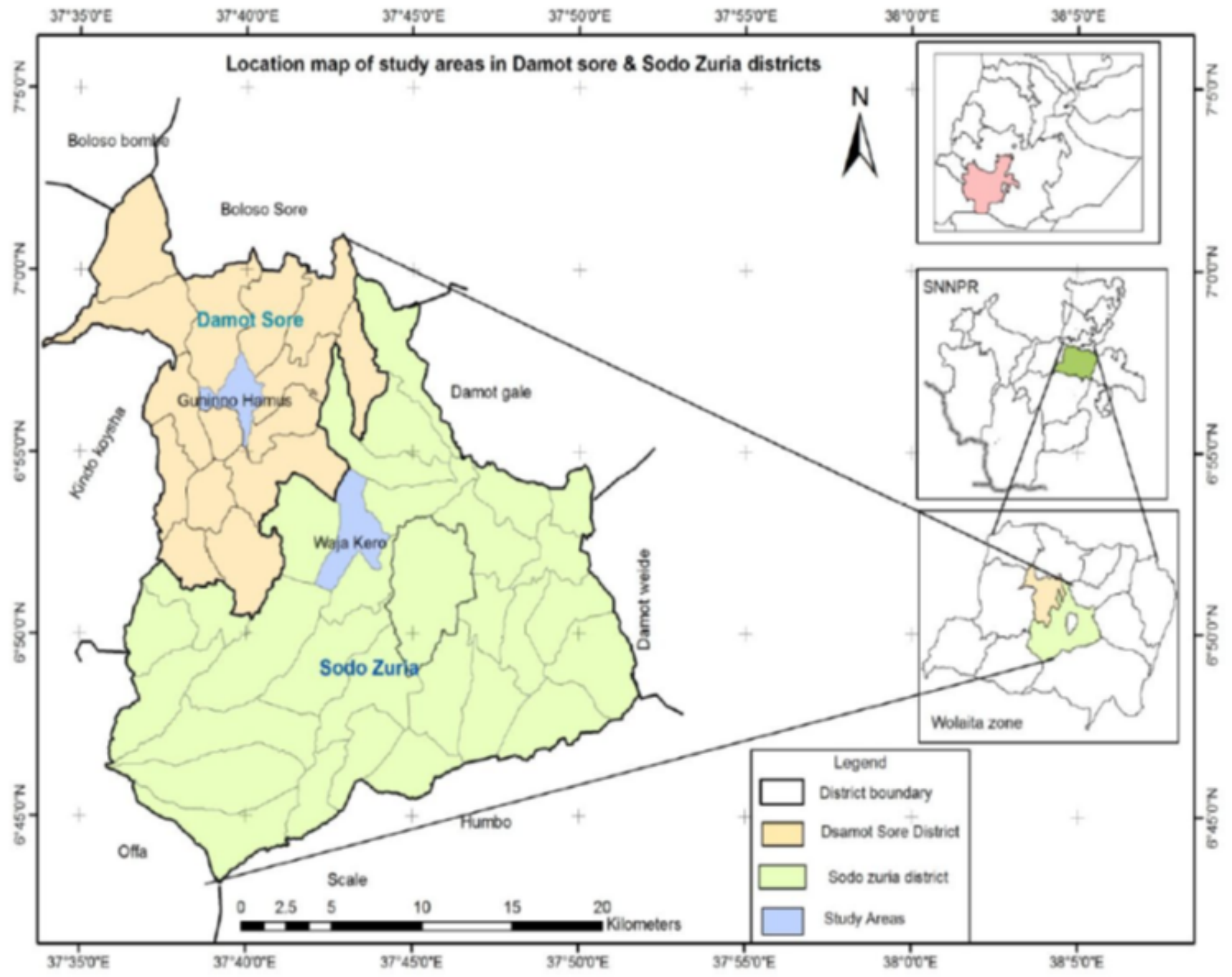

Figure 1

Location map of the study areas in Wolaita Zone (Damote sore and SodoZuria Districts). 


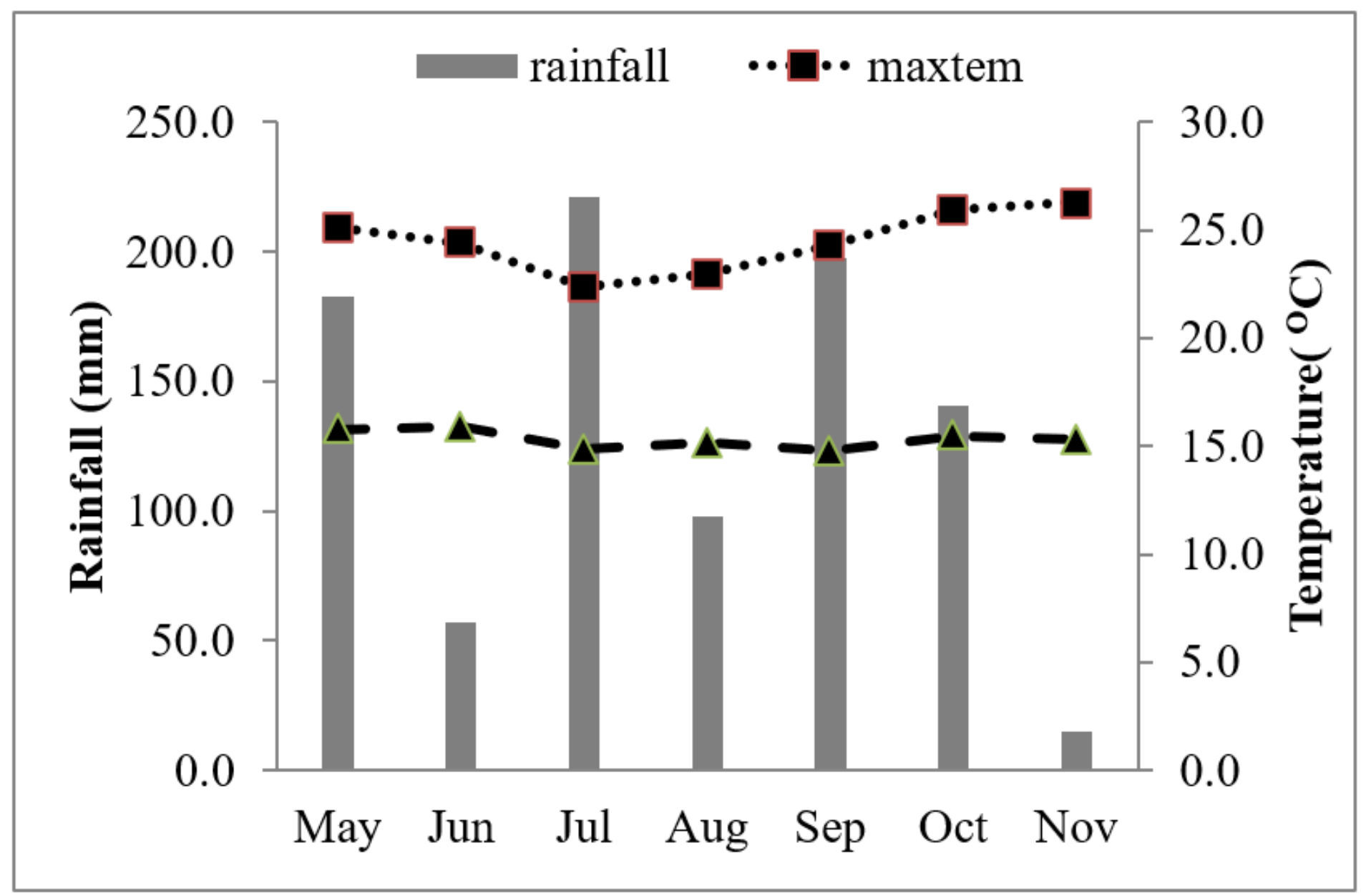

Figure 2

Mean monthly total rainfall $(\mathrm{mm})$, maximum and minimum temperatures $\left({ }^{\circ} \mathrm{C}\right)$ of the study areas from 2016 2017 (Source: National Meteorological Agency, Hawassa branch).

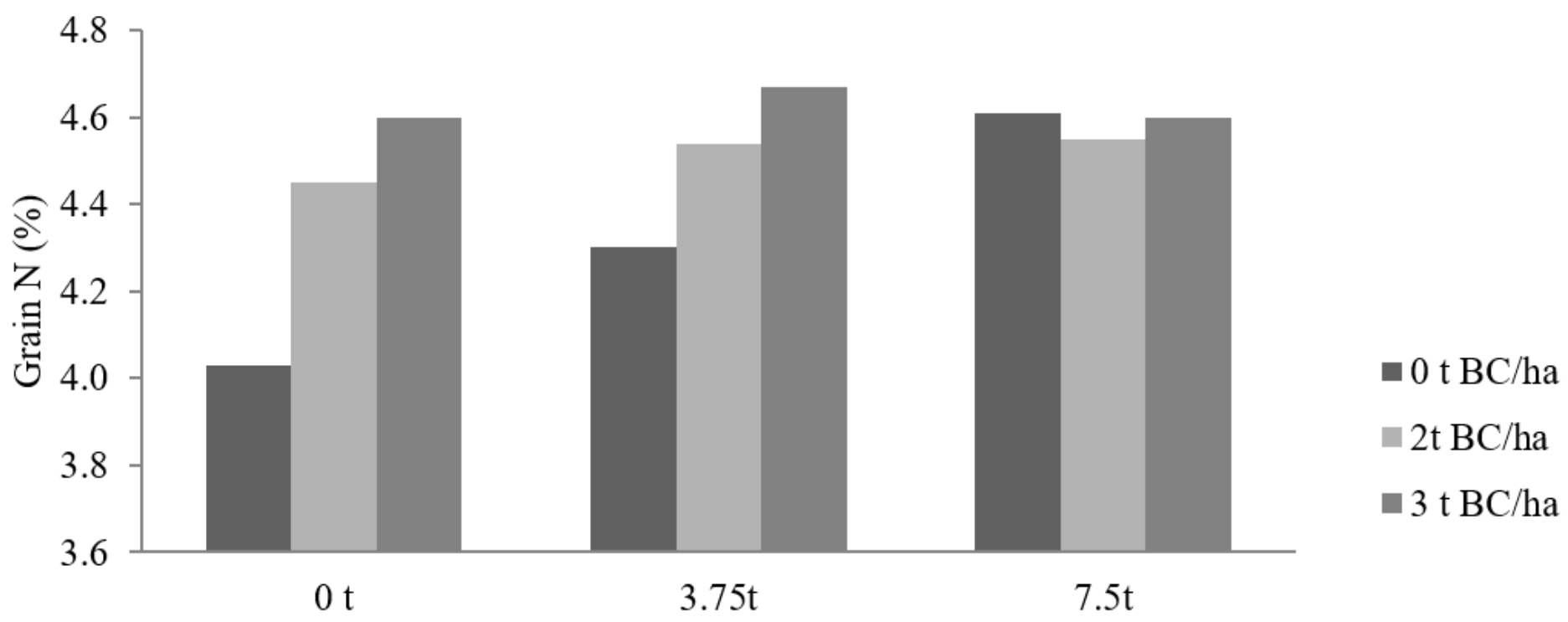

Lime rate ha ${ }^{-1}$ 
Figure 3

The Effect of $\mathrm{BC}$ and Lime interaction on grain $\mathrm{N}$ content (\%) of wheat

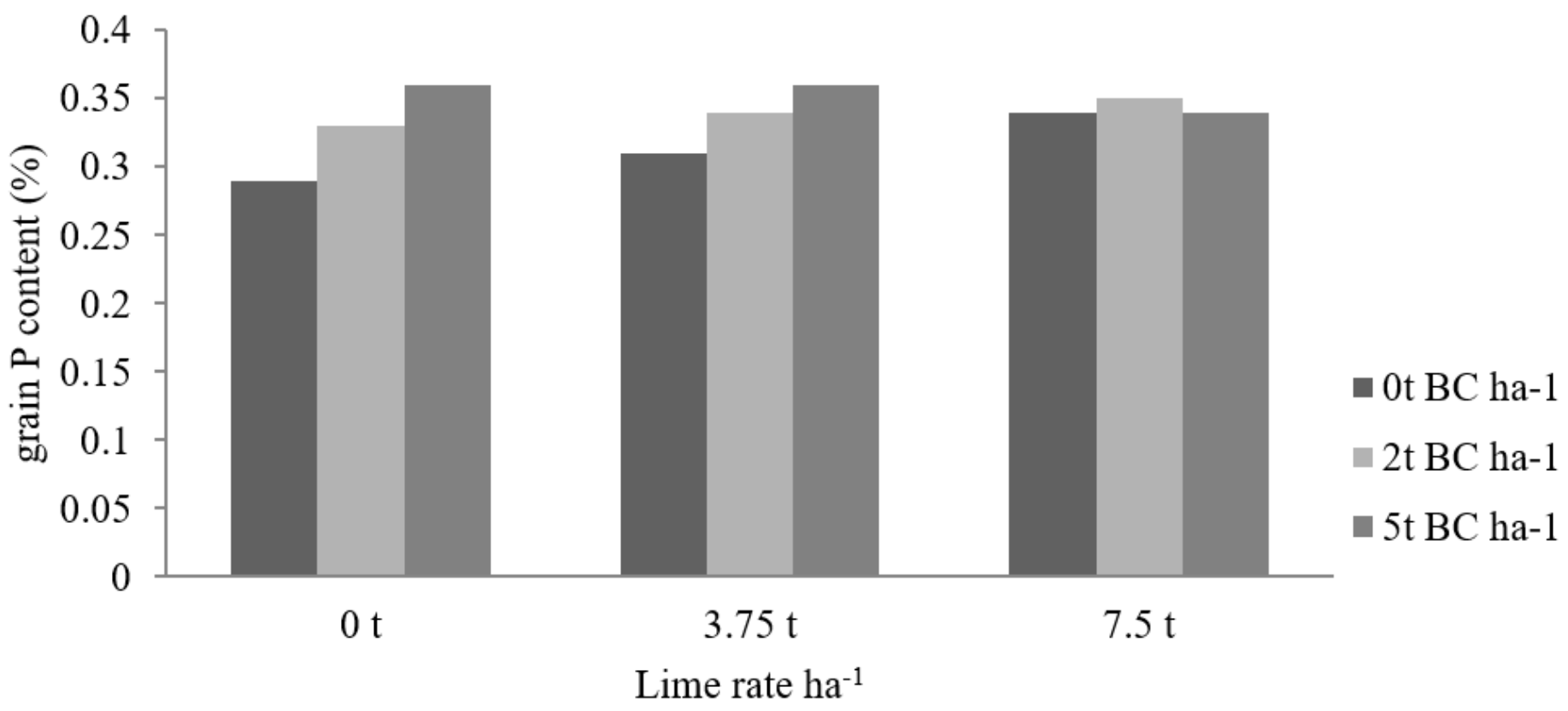

Figure 4

The effect of $B C$ and lime interaction on grain $\mathrm{P}$ content of wheat

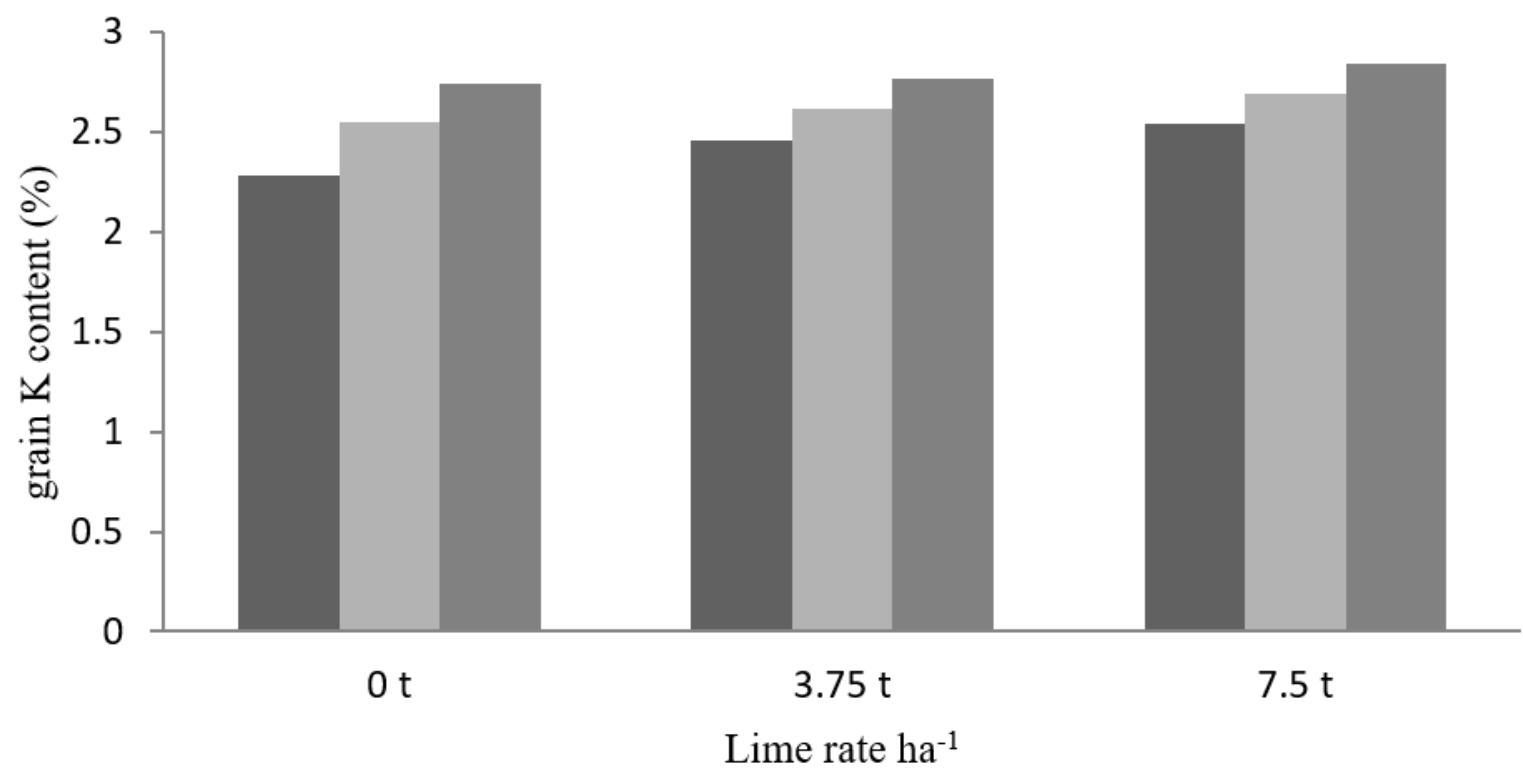

- 0t BC ha-1

$\approx 2 \mathrm{t}$ BC ha-1

-5t BC ha-1

Figure 5

The effect of $B C$ and lime interaction on grain $\mathrm{K}$ content of wheat 